\title{
To the Use of Etymological Methods in the Research of the Origin of Slavs
}

\author{
Georgiy M. Telezhko \\ Sole Proprietor \\ 凶yurate@bk.ru
}

Introduction. This article is written in the development of the theme of the application of linguistic methods to historical research, more specifically, to the research of the circumstances of the origin of the Slavic ethnic group. These circumstances have not yet been clarified to the extent excluding clashes of opinions, down to opinions opposite to each other. In particular, the range of supposed dates for the appearance of the Common Slavic language varies from the $3 r d$ millennium BC to the middle of the 1 st millennium AD. The article describes an attempt of restricting this range.

Methodology and sources. The main ethno-defining trait is a common language: the Old Russian lexeme газыкъ meant both "ethnos" and "language". Usually a common language is, according to O. N. Trubachev, the result of convergence of many originally different dialects. The search for the probable time of the Common Slavic language origin has been accomplished under the following assumption: the factor consolidating dialects into the Common Slavic language ("Slavic Koine") were kinds of economic activities that spanned a number of tribal groups, including the group of speakers of the actual Proto-Slavic dialect that initiated these activities.

The type of this production can be tried to determine by the ancient original Slavic industrial terms. Then, assuming the possibility of migrations of Proto-Slavs from the territory where the Common Slavic language was formed, to the territory inhabited by foreign-speaking tribes, we have searched for the names of local flora and fauna borrowed in Slavic languages, as well as foreign-speaking place names; in the languages of ethnic groups currently living in the territory of the formation of the Common Slavic language, we must, accordingly, find traces of Slavic names of local flora and fauna, as well as toponyms, Slavic by origin.

Results and discussion. Examining Slavic vocabulary, we have found there: a) Common Slavic names of copper, lead and silver, i. e. metals that have been simultaneously found in Old Europe exclusively in the Balkan-Carpathian metallurgical province of the 4th millennium BC; b) the original Slavic terms related to mining and metallurgy; $c$ ) the original Slavic names of crops and a number of other plants native to the Eastern Mediterranean and neighboring areas, as well as the names of the agricultural inventory; d) Finno-Ugric borrowings of the names of Northern European fish and Finno-Ugric place names in the absence of German borrowings. In the languages of peoples living in the Eastern Mediterranean one can find zoonyms, phytonyms and place names with unclear etymology, which, upon closer examination, can be explained as borrowings from dialects of the Proto-Slavic language.

Conlcusion. The totality of the observed lexical data leads to the conclusion that the ancestral home of Slavs was localized in the Eastern Mediterranean. This data does not correspond to any of other Indo-European (IE) languages other than the Baltic languages, 
which suggests, in particular, that only Proto-Slavs and Proto-Balts were directly related to the Balkan-Carpathian Metallurgical Province of the 4th millennium BC and that the languages of the respective groups were being formed in the Balkans and the Eastern Mediterranean at that very time.

Keywords: ethnogenesis, Slavs, Illyrians, Balts, Thracians, Germans, homeland, mining vocabulary, copper, lead, silver, crops, etymology, original terms, borrowed terms.

For citation: Telezhko G. M. To the Use of Etymological Methods in the Research of the Origin of Slavs. DISCOURSE. 2021, vol. 7, no. 1, pp. 103-124. DOI: 10.32603/2412-8562-2021-7-1-103-124

Conflict of interest. No conflicts of interest related to this publication were reported.

Received 28.07.2020; adopted after review 01.09.2020; published online 25.02.2021

\title{
К применению этимологических методов в исследованиях происхождения славян
}

\author{
Г. М. Тележкко \\ Индивидуальный предприниматель \\ 凶yurate@bk.ru
}

Введение. Данная статья написана в развитие темы приложения лингвистических методов к историческим исследованиям, более конкретно: к исследованиям обстоятельств возникновения славянского этноса. Эти обстоятельства до настоящего времени не прояснены в той степени, которая не вызывала бы столкновений мнений, вплоть до противоположных. В частности, диапазон предположительных дат появления общеславянского языка разнится от 3-го тысячелетия до н. э. до середины 1-го тысячелетия н. э. В статье описана попытка сужения этого диапазона.

Методология и источники. Основным этноопределяющим признаком выбран общий язык: в древнерусском лексема газыкъ означала и «народ», и «язык». Обычно общий язык, по О.Н. Трубачеву, является результатом конвергенции многих изначально различных диалектов. Поиск вероятного временного диапазона возникновения общеславянского языка был произведен при следующем допущении: фактором, консолидирующим диалекты в общеславянский язык («славянское койне»), являлись виды хозяйственной деятельности, охватывавшие некоторое множество племенных групп, включающее группу носителей собственно протославянского диалекта, которая инициировала эту деятельность.

Виды такой деятельности можно попытаться определить по древнейшим исконно славянским промышленным терминам. Далее, предполагая возможность миграций протославян с территории, где формировался общеславянский язык, на территорию, населяемую иноязычными племенами, мы произвели поиск заимствованных в славянские языки названий местной флоры и фауны, а также иноязычных топонимов; в языках этносов, живущих в настоящее время на территории формирования общеславянского языка, мы, соответственно, должны найти следы славянских названий местной флоры и фауны, а также славянских по происхождению топонимов.

Результаты и обсуждение. В результате изучения славянской лексики в ней обнаружены: а) общеславянские названия меди, свинца и серебра, т. е. металлов, одновременно встречающихся в Древней Европе исключительно на территории БалканоКарпатской металлургической провинции 4-го тысячелетия до н. э.; б) исконно славянские по происхождению термины, относящиеся к горному делу и металлургии; в) исконно славянские названия сельскохозяйственных культур и ряда других расте- 
ний с родиной в Восточном Средиземноморье и прилегающих территориях, а также названия сельхозинвентаря; г) финно-угорские заимствования названий североевропейских рыб и финно-угорские топонимы при отсутствии германских заимствований. В языках народов, живущих в Восточном Средиземноморье, обнаруживаются зоонимы, фитонимы и топонимы с неясной конечной этимологией, которые при внимательном рассмотрении могут быть объяснены как заимствования из диалектов протославянского языка.

Заключение. Совокупность приведенных лексических данных позволяет сделать вывод о локализации прародины славян в Восточном Средиземноморье. Этим данным не соответствует ни один из прочих индоевропейских языков, кроме балтийских. Это позволяет предполагать, в частности, что только протославяне и протобалты имели прямое отношение к Балкано-Карпатской металлургической провинции 4го тысячелетия до н. э. и что языки соответствующих групп складывались на Балканах и в Восточном Средиземноморье именно в это время.

Ключевые слова: этногенез, славяне, иллирийцы, балты, фракийцы, германцы, родина, горнорудная терминология, медь, свинец, серебро, сельскохозяйственные культуры, этимология, оригинальные термины, заимствованные термины.

Для цитирования: Тележко Г. М. К применению этимологических методов в исследованиях происхождения славян // ДИСКУРС. 2021. Т. 7, № 1. С. 103-124. DOI: 10.32603/2412-8562-2021-71-103-124

Конфликт интересов. О конфликте интересов, связанном с данной публикацией, не сообщалось.

Поступила 28.07.2020; принята после рецензирования 01.09.2020; опубликована онлайн 25.02.2021

Introduction. Despite the variety of articles and monographies (to see that one could look through a comprehensive review done by V. V. Sedov [1, p. 7-48]) about linguistical ethnogenesis of Slavs, i. e. about the history of evolution of a language community called Slavic language group nowadays, there is still no common point of view either on the time of separation of the Proto-Slavic language (or Proto-Slavic dialects) from the Indo-European proto-language, or on the territory in which the Proto-Slavic language was formed ("the Slavic homeland").

Most attempts to solve the problem of linguistic ethnogenesis of Slavs or, according to O. N. Trubachev, "the problem of reconstructing the ethnic history, ancient culture of the ancestors of Slavs with the help of linguistic reconstruction" [2, p. 10], can be divided into three groups. These are Eastern European, Vistula-Oder and Danube theories. Presence of Slavs on each of the mentioned areas (Eastern Europe; the area between Vistula and Oder; the Danube river region) is the basic argument in favor of each of the three theories.

A part of the previous paper [3, p. 10-12] presented a brief comparative analysis of pro and contra arguments in discussions of the said theories of the Slavic homeland, which arguments still lead to no definite solution of the problem. Arguments from the fields of archaeology, history, geography, botany, genetics and linguistics have been considered.

This article is another attempt to analyze accessible relevant language data, which, to our opinion, could reduce the uncertainty of ideas about the time and territory when and where the Proto-Slavic language had been formed, discovering traces of the Slavic homeland in East Mediterranean.

Methodology and sources. The archaism of Slavic languages [4, p. 76, with reference to A. Meillet] must have resulted from relative isolation of native speakers of Proto-Slavic dialects 
from native speakers of other dialects of the Indo-European (IE) language during its disintegration and, possibly, for a long time after it. Although there is also no common opinion regarding IE ancestral home, all the three theories of the Slavic homeland to a certain extent satisfy the condition of relative isolation of Proto-Slavs from the rest Indo-Europeans, were they in Anatolia, in the Northern Black Sea region or in Northern India. But whether the ancestors of Slavs lived in the same territories as nowadays or not is still in question.

Talking of the ancestors of Slavs, it makes sense to clarify first whether we mean the speakers of the Proto-Slavic dialect of the IE language or we mean the speakers of the group of dialects from which the Proto-Slavic language had been formed over time. O. N. Trubachev shares the second view on the origin of the Proto-Slavic language:

"Different approaches point out that any language is an integration, that the Slavic language type is the result of consolidation, that it is appropriate to talk about the multicomponent nature of each language and finally, the available written sources of ancient eras directly show that the further back into centuries, the greater was the number of languages, not less. ... one can often find an expression like 'Slavic ethnolinguistic association' ...” [5, p. 16].

"...We must proceed from the collective nature of the Indo-European or Proto-Slavic speaker, as well as the user of any other lexical fund” [5, p. 94].

The point of view of $\mathrm{O}$. N. Trubachev on ethnogenesis as a process of dynamic combination of various cultural and linguistic factors seems right. It is difficult to imagine the opposite, i. e. that people in a certain territory suddenly start speaking the same language or always and invariably spoke the language of the first one who spoke it, so that his language did not experience any further influence from new interlocutors or neighboring languages.

Trying to find the territory where Proto-Slavic language could have originated we should begin with clarifying the criteria for such a territory, which work has been done recently [3, p. 13].

First, we must have in mind that consolidation of dialects into a common lingua franca should result from the objective necessity for such a consolidation. The territory of such a language should be either an area of a large-scale production process with developed trade covering several ethnic groups, or a zone of influence of an ethnos that is technologically ahead of its neighbors. In such lingua franca, traces of the terminology associated with this production or the names of artifacts of the leading ethnic group should remain.

If speakers of this lingua franca went on living in this territory never leaving it, we might expect that the descendant language(s) would have a common landscape vocabulary (including toponyms), common names of local animals (including fish, insects, etc.) and plants, cultivated ones in that number.

Of course, if for some reason speakers of this language had been forced to leave their ancestral home, then our study is going to be somewhat more complicated. But even in this case, we can hope to establish the fact of migration, or even to find its initial point.

For example, we could find some borrowings among weather and landscape terms, among the names of local animals, plants, etc., the sources of which are lexemes used in the newly neighboring languages. Such borrowings indicate the arrival of the ethnic group under study from an area where objects and phenomena with borrowed names were not known.

Similarly, we can search for toponyms, technical and economic terms, names of representatives of exotic flora and fauna not known to aliens, etc., borrowed from the suggested 
lingua franca, in the languages of ethnic groups that replaced the ethnos under study at the starting point of its migration.

Third, due to the continuity of the history of the ethnos, the original craft, household, economic and social vocabulary can also tell us about earlier places of its habitation. In the language of migrants who left the ancestral home, the names of artifacts that were taken to new habitats could be preserved. First of all, this concerns the original names of ancient crops and the original names of ancient metals.

The continuity of such vocabulary is parallel to one of the migration criteria known in archeology, namely, the continuity of the artifacts themselves at the final point of the supposed migration with respect to its starting point. This parallel is heuristically useful, since ancient metallurgical provinces and the starting points of diffusion of cultivated plants are well studied.

What theory of the Slavic homeland, in the end, should we dwell on?

According to Trubachev, the modern Vistula-Oder concept more likely describes not the initial ancestral home of Slavs but their further migration from the Vistula-Oder region to the east, where the ancestral home is found by supporters of the East European theory.

This lets us consider all the above theories as not describing different candidates for the Slavic initial homeland, but homes consequently "occupied” by Proto-Slavs. Such a synthetic approach lets us, for example, explain the absence of developed terminology regarding sea and mountains in the Slavic vocabulary: such terminology is doomed to be washed out of the language over several generations since it is obviously unnecessary in the flat-swamp-lake landscape of Eastern Europe where written history for the first time captures the habitat of Slavs.

Results and discussion. Let us turn to testing the hypothesis of ancient migrations of ProtoSlavs from the Danube area using linguistic methods. We will have in mind that mining and metallurgy are examples of large-scale production providing conditions for convergence of local tribal dialects of people engaged in the work. If the Proto-Slavic language had originated in this area, including the Balkans and Carpathians, then it would have formed native terms for metals excavated in this very region, mostly, copper (Rudna Glava and Ai Bunar mines), lead and silver (Laurion mines).

\section{Slavic terms of mining and metallurgy}

It is striking that the Slavic terms for copper and lead are unique among the IE terms and seem original, and the Slavic terms for silver only have a common origin with those of Balts and Germans. Furthermore, it is worth attention that Rus. names for mercury, copper, silver, tin, lead and iron do not have any IE prototypes. This is possible, for example, in case if the ancestors of Slavs lived in places where they could discover these metals by themselves being relatively isolated from other IE ethnic groups, except Balts, with whom there was a significant craft terms exchange [6, p. 48-50], and/or Germans. In most cases names of metals passed along with the metals themselves (for example, the Latin name for copper was distributed almost throughout Europe, and Slavs borrowed the names of many metals in cases they had been discovered by others).

However, there is a possibility of appearance of native names even for imported goods and materials: importers could rename the original names their own way, for example, for comfortable pronunciation or for making the names' sense clear by means of the original names' deformation or their translation into the importers' own language. Analysis of corresponding 
technical terminology would help us to reduce the probability of such cases in relation to mining and metallurgy: if the technical terms are original, then the names of mined metals are also most probably original.

To a large extent, mining in Slavic languages has been using original Slavic terms:

- Rus. копи "a mine” is a cognate word with the original Rus. копаю "I dig";

- Rus. креnь "a construction to prevent rock collapse in mines" is a cognate word with the original Rus. креплю "I strengthen”;

- East Slav. pyda "ore; blood" is considered as a term of Slavic origin, cognate with several IE lexemes meaning reddish colors (see "руда" [7]);

- лом “а crowbar" and лоnата "a spade” are considered as absolutely original Slavic (see “лом”, “лапа”, “лопата” in [7]).

The Rus. term кайло "a kind of hammer" has no definite etymology, hence it needs a more thorough etymological consideration. Some compare it with German Keil "wedge" < OHG kil “to split” [8], which, according to Vasmer, is not likely (see “кайло” in [7]). Therefore, we suggest to consider a typical Rus. word formation mode with a productive suffix -l-, e. g.:

- стойло "а stall" < стоять "to stand";

- хайло "а throat" (slang) < хаять "to speak badly of an absent individual, to backbite";

- пойло "swill, a drink of low quality" < noumb "to water, to give one’s drink".

Using the same word formation standard, we could produce кайло from Rus. каять "to blame, to reproach, to condemn" (cognate with OInd cáyatē "punishes" and Avest. kaēnā "punishment") if it were not for the semantic mismatch between the notion of instrument and the notion of guilt/punishment.

However, if we recall public executions in the form of stoning at ancient times, we might suggest the gradual drift of sense "to stone" > "to punish" > "to condemn, to blame, to reproach" thus assuming that кайло "а kind of hammer", каять with the original meaning "to stone" and камень "a stone" are cognates, having a common ancient root *ka-. As for semantic drift "stone" > "hammer", compare OHG hamar "hammer" and ONorse hamarr "stone", both with the root ha- < *ka-. If so, then кайло "a kind of hammer" can be considered as a cognate with камень "a stone”, i. e., as a term of Slavic origin.

These and similar terms had been saved through centuries, because the work with minerals (search and mining) went on no matter whether migrations took place or not.

ORus. terms from the vocabulary of metallurgists and blacksmiths are also well-known:

- ORus. дъмьница, домница "a blast-furnace”, from an ancient stem *do-, from which also

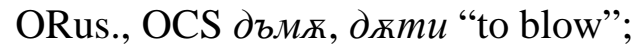

- ORus. blacksmith craft terms (гърнъ “а furnace”, молоть “a hammer”, ковати “to forge”, кузнь “а forge”).

An IE form *kou- (referring to Starostin, *kows-) acquired the meaning "to forge" in no languages except Slavic: the stem means "to kill” in Tocharian and Iranian languages, "to beat”, "to chop" in German ones; while the meaning "to forge” [9, p. 725], (see “*kowə-” in [10]) developed in Slavic languages only. Proto-Slavic *kuznb "forged products" is obviously an original Slavic form from the stem *ku- in *kuti "to forge" by a typical scheme with the formant -зн- [zn], as in Rus. жизнь < жить, боязнь < боять(ся), болезнь < болеть.

We are not considering here ancient terms, related rather to pottery than to blacksmith craft, for example, *pekt'b [9, c. 713], as irrelevant. 
Some other ancient and original metallurgical terms, such as Proto-Slavic dialectal *ěstěja “устье печи” (reconstruction by O. N. Trubachev using related Slovenian dialectal vesteje and istéje, jistje; OCzech niesteje, nístěj, Czech dialectal nístěj, Slovak nistej, Upper Lusatian něsć, Lower Lusatian jěsća, jěsće, jěsćija, jěsćije) [11, p. 145], *kladivo “hammer”, *vygnb “forge” are worth mentioning about, because they had been saved in the area where we are searching for the ancestral home of Slavs: in Slavic languages of the Middle and South Danube [5, p. 89]. Traces of *vygnь are saved in Serbo-Croatian виїан, Macedonian вигна, Slovenian vigenj, Moddle Bulgarian выгнии "a forge”, in Slovak vyhňa and Czech vyheň, but not in Polish and East Slavic languages.

The first lexeme *ěstěja was directly derived by Trubachev from an IE stem *ěd- meaning "to eat" [9, p. 698]; the lexeme *kladivo is obviously derived from Proto-Slavic *klad-ti, and the lexemes meaning "a forge” < *vygnь are related to ORus., OCS огнь, Bulgarian ózън, Czech, Slovak oheň.

There is little doubt that the above Slavic mining and blacksmith terms are original. Besides original blacksmith terms there are also several late borrowings in Slavic languages, mostly names of the blacksmith inventory [9, p. 700], but they do not damage the originality of the most ancient Slavic craft terms reviewed above. This makes sure that Slavic unique names for copper and lead are also original, i. e. they are not result of adaptation of any foreign original names.

Now we should focus on the etymological sources of Slavic names of copper, lead and silver (as there is no consensus on the origin of these names in literature) which were mined in the vicinity of Danube in ancient times. We will omit the etymological study of the name железо "iron" since O. N. Trubachev has persuasively written about the Slavic origin of this name [5, p. 124-129].

As we can see in the Table, all Slavic names for copper, lead and silver have been derived from corresponding common stems (except later names of lead in Rus., Ukr., Blr. and Slovenian, which replaced ORus./OCS олово), i. е. each of these names has a common Proto-Slavic origin, which points on their antiquity, preceding the Proto-Slavic language disintegration.

Slavic names of copper, lead and silver

\begin{tabular}{|c|c|c|c|}
\hline State & copper & lead & silver \\
\hline Russian & медb & свинец & серебро \\
\hline Ukrainian & мідb & свинецьь & серебро, срібло \\
\hline Belorussian & медзь & свінеи & серабро, срэбра \\
\hline Old Russian & $\mu \sqcap \partial b$ & олово & сьребро > серебро \\
\hline Old Church Slavic & мйдb & олово & сьребро, съребро \\
\hline Bulgarian & мед & олово & сребро́ \\
\hline Serbian & мјёд & ойово & срёбро \\
\hline Slovenian & mẹ d & svinec & srebrộ \\
\hline Czech & měd' & olovo & stř́ibro \\
\hline Slovak & med' & olovo & striebro \\
\hline Polish & miedź & olow & srebro \\
\hline Upper Lusatian & mjedź & wołoj & slébro \\
\hline Lower Lusatian & měź 'brass' & wołoj & slobro, slabro \\
\hline
\end{tabular}




\section{Медb "copper"}

For the Proto-Slavic name of copper, we will offer the reconstruction $*_{M h n} \partial_{b}$ [mjędb] "something flexible", which is related to OCS $м \wedge m u$ "to knead". The morphological relation

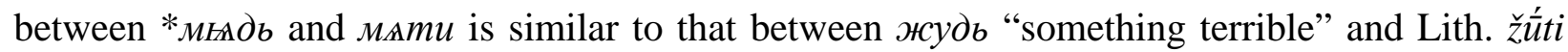
“to perish” (see “жуда" in [7]) assuming OCS cognate *жоути "to perish”.

The semantics of $*_{M L n} \partial b$ "something flexible" reflexes the significant for the ancient people difference between free copper and stones: when struck by a solid object copper deforms, not breaks. This feature can be clearly seen in an ORus. term ковъ "соррег” which is related to ковати "to forge" [12, p. 127], i. e. copper is a malleable, deformable material. Compare the old name for silver in Finnish, hopea, which is related to words meaning "soft", "flexible” [13, p. 82].

In ORus., according to the common rule, the prototype ${ }^{*}{ }_{M ц} \partial b$ should give ${ }^{*}{ }_{м я \partial b}$, but not $\mu r \partial b$, after the reduction of nasals. But there is a quite archaic example of the similar exceptional correspondence, which almost completely matches with the case we reviewed above, compare:

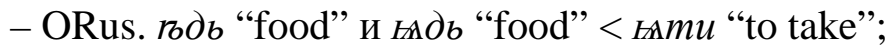

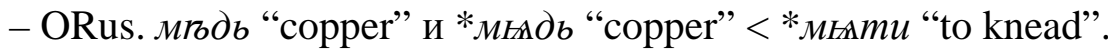

It is known that Baltic names of copper are not related to Slavic ones: Lith. varis, Lett. varš, which originate from the stem with the meaning "to boil” [6, p. 48-50]. This is the only discrepancy between Baltic and Slavic metal names, and it definitely shows the difference in the circumstances under which these ethnic groups first became acquainted with copper: Proto-Slavs discovered the softness of free copper, and Proto-Balts smelted copper from ore.

O. N. Trubachev also mentions the difference between Slavic and Baltic blacksmith terms (with the exception of OCS въmps and OPrus. wutris "blacksmith") [9, p. 725]. These oddities can be explained by the historical division of labor in the Balkan-Carpathian metallurgical province (ore mining vs. product manufacturing: copper was smelted and copper products were produced far away from the mines where copper ore was mined) [14, pp. 138-139]. This provides us with one more argument in favor of location of Slavic homeland somewhere in between Balkans and Carpathians where Proto-Slavs could contact with Proto-Balts.

We should also mention that the Proto-Slavic stem *kow-/*ku- of the Novgorod dialectal copper name can be seen in Hittite kuwanna and Luwian kuwanzu "copper". This could indicate that these peoples only were involved in metalworking, not in smelting of copper ore. The trace of this stem had also preserved in Ancient Greek $\kappa v \alpha v o ́ \varsigma$ "copper azure (glass stained with copper oxide acquires blue color), blue-black (the color of copper oxide)"; with unclear etymology [15]. This could be attributed to the influence of language of a group advanced in metallurgy on languages of neighbors - Balkan-Carpathian province left Anatolia behind in production of copper [16, p. 62].

Серебро "silver"

Proto-Slavic *sbrebro "silver", among other ideas (e. g. [13], "cepeбpo" in [7], etc.), can be compared to Persian sorb < Middle Persian srub, Tajik cypб, Kurdish sirb (all meaning "lead”), the further etymology being not given (see سـرب in [8]).

We can suppose the following story of Iranian lead names, related to the Proto-Slavic silver name (we exclude the idea that ancient Iranians did not differ silver and lead).

Lead is smelted in the process of thermal decomposition of galena, lead sulfide, in which process sulfur dioxide is emitted, which has a pungent odor. Moreover, since galena is a silver- 
containing ore, silver was a by-product of lead smelting. Sulfur in a free state, as well as the pungent smell of burning sulfur and the disgusting smell of hydrogen sulfide, has been known since ancient times. Because of this, there are etymological hypotheses explaining both the Slavic name of sulfur and silver, and the Iranian names of lead.

Due to the disgusting smell of sulfur compounds, we can logically assume that ORus. cropa is related to Slavic *sbrati "to defecate, to shit" with the alternation $r o \sim b$, just as dropa "hole" дьрати "to tear", жтртва "sacrifice" жьрати "to eat, to deavour". Hence the possibility of a suffixal derivative *sbroba "rubbish, shit" (like хвороба "illness, ailment" from *xvorъ "ill" and зълоба from зъль "evil”), from which the Iranian lead name and ORus. сьребро "silver" were derived (as добро "goods" - from доба “а (suitable) time” (see “добрый” in [7]). Harper gives an OCS analog without the suffix $-r$ - (s(u)rebo) (see "silver" in [17]), also one can find the spelling сребо "silver" in Bulgarian texts. Trubachev writes differently about серебро [13, p. 76-82], but his etymological variants do not explain the connection between Iranian lead names and Slavic silver names.

German names for silver are probably connected with sulfur name independently: compare Sanskrit śulbāri, OLat. sulpur "sulfur" with OE seolfor, Mercian sylfur "silver; money”, OSax. silvbar, OFris. selover, ONorse silfr, OHG silabar, Goth. silubr "silver” (see "silver” in [17]).

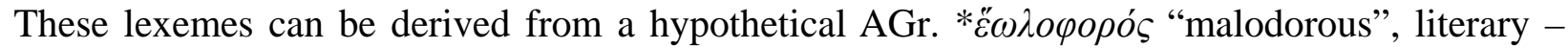
"stench-carrying", with the specific correspondence of Latin and German [s] to heavy Greek

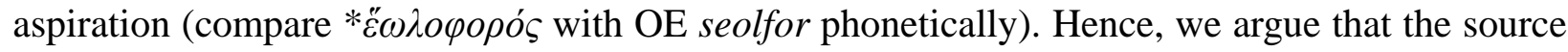
of German names for silver differs from that of Slavic names, despite similarity of semantics and pronunciation.

Свинеи “lеad”, олово "tin”

Lead artifacts witness about lead metallurgy, since lead in its pure form is rare in nature. The earliest items made of lead (beads and pendants) had been found in Çatal Höyük (the 6th millennium BC [18, p. 17]). It can therefore be assumed that the most ancient name of lead was born somewhere in the south of Asia Minor. We do not know which language: Hatti, Sumerian or any of Semitic languages, gave a name to lead first.

People started smelting lead no later than 4th millennium BC on the Aegean islands: many lead products had been made in the 3rd millennium on Crete. From the beginning of the 3rd millennium BC lead products became known also in Ancient Egypt [18, p. 17-18]. Trade contacts of Cretans reached Spain at that time; Cretan lead products found in Spain witness this. [19, p. 60].

Lead weights for scales based on the Minoan unit of weight which were being found throughout the Aegean region indicate that the entire Aegean region in the Minoan era was embraced by unified trade relations, a heritage of the Cycladic culture of the 3rd millennium BC [18, p. 17-19]. Given the presence of Cretan artifacts in Spain, we can talk with certainty not only about developed metallurgy in the Aegean region, but also about developed shipping.

Such diffusion of lead products in the 4th-3rd millennia BC should have been accompanied by the spread of the original name of lead, born in the language of its manufacturers.

In most of Slavic languages the stem * $(w)$ olow- was used for naming lead. The etymology of олово "lead", for semantic reasons, is derived the following way: it is the prefixal derivative from the stem *low-, whose cognate is лumb "pour", due to the fusibility of lead (heated in flame of a fire, it melts and flows or can be poured). The scheme of formation is typical: Rus. олово < 
лить, like омовение < мыть, the morphemic structure of $о$-лов-о соincides with that of Rus. о-ков- $а$, о-снов- $a$.

Related to old пловкий “fusible”, лой “fat”, hydronym Ловать/Ловоть, олови́на - “brew, beer, mead; in dialects - sediment; brew, beer or kvass leftovers" [20] - i. e., liquid which is poured or its leftover remaining after pouring off.

Contrary to Vasmer (see “олово” in [7]), Slavic *(w)olow- "lead” is not related to OHG ëlo “yellow”, Lat. albus “white”, Greek $\alpha \dot{\lambda} \varphi o ́ \varsigma$ “white lichen”, since the color of lead no way can be considered as white or yellow.

Mikkola supposed (with doubts of Vasmer (see “олово” in [7])) that the Slavic term had been borrowed from the same Mediterranean source as Rhodes $\beta o ́ \lambda \imath \mu o \varsigma$ "lead” and Lat. plumbum "lead" (Vasmer agrees that the Greek and the Latin terms have the same origin). We believe that the direction of borrowing was the following: Proto-Spavic *(w)olow- > Rhodes $\beta$ ó $\lambda \mu o \varsigma$, with phonetic changes $[\mathrm{w}]>[\mathrm{m}]$ and $[\mathrm{w}]>[\mathrm{b}]$ similar to those in Akkadian dialects in the $2 \mathrm{~d}$ millennium BC [21, p. 125].

The close relation of Slavic and Baltic lead names with the IE stem * $I V w$ with the meaning of fluidity (and the absence in other languages of any names close to them) obviously result from noticeable isolation of Proto-Balts and Proto-Slavs from other IE dialects speakers in the era when smelting of lead from ores began.

The applying of related terms both to lead and tin in Slavic languages can only be explained by the fact that both metals are fusible (and we should remind that lead is by no means albus “white”).

In some Slavic languages relatively late names for lead have appeared: Rus. свинеи, Ukr. свинець, Blr.. свінец, ORus., Church Slavic свиньцьь, Slovenian svínac. Rus. свинеи is more likely related to Rus. свин "male pig, boar", i. е. свинеи is "dirty, pig metal”, compare the semantical parallel: чушка "ingot" from чушка "piglet", also mind pig iron.

The way of word formation is typical for ORus. and OCS: свинъ > свиньиь like конъ > коньиь, образъ > образьциь. Modern East Slavic lead names were evidently applied to differ it from tin. Tin also was considered as "white lead”, and lead was considered as "black lead”, both metals being similarly opposed to each other in some Altai languages and in Latin.

Modern Baltic names for lead are Rus. borrowings and thus cannot be the sources for the original Eastern Mediterranean names for lead.

So, we made sure that:

- there were metallurgy centers mining and smelting copper, lead and silver in the BalkanCarpathian region at ancient times (from the 4th millenium BC); the region was in relative isolation from Near East and Africa;

- Slavic languages have original mining and metallurgical terminology having original names for copper, lead and, probably, for silver as well, the names differing substantially from those in other IE languages, with a few exceptions (e. g., names for silver in Baltic and German languages);

- thus, we have reason to believe that Slavic names for at least copper and lead, which were mined in ancient times in this region, have Slavic origin.

This suggests that the ancestors of Slavs during the development of metallurgy in the Balkan-Carpathian region had a direct relationship to this development, i. e., they obviously lived there in the 5th-3rd millennia BC. 
Even if the Slavic etymology of silver is left in doubt, the hypothesis about the origin of Slavic, Baltic and German names for silver from some of the Southwest Asian sources, as well as the hypothesis about the origin of Slavic and Baltic names of iron from the Hittite language [18, p. 99] yet do not contradict the idea about formation of the Proto-Slavic language in Southern Europe, not in the North-East.

The mere fact that locals were acquainted with local resources was not enough for all of them to call these resources the same way. The important thing is that mining industry, metallurgy, blacksmithing and trade formed an industrial complex with extensive cooperation of many people from different local tribes involved in the production process who initially might have spoken different languages or different dialects of the same language. This cooperation had created the need for the language consolidation which O. N. Trubachev mentioned [5, p. 16] and which led to the formation of the Slavic language type.

\section{Slavic names for crops and agricultural tools}

If the Proto-Slavic language was being formed at the end of Chalcolithic period in the Eastern Mediterranean, Slavs should have common names for crops native to this region and names of agricultural tools from the Chalcolithic and Bronze Age.

It is utterly true for Rus. names of the following plants:

- ячмень "barley”, пшеница "wheat”, просо "millet”, жито "grain, cereals”, often - "rye”, горох "реa” are original Slavic, they have no analogues in other Indo-European languages; wherein жито, пшено "groats of millet” и пшеница are ranked as late derivatives from lexemes with the meanings "to live" and "shove" respectively;

- рожь "rye” is original Slavic, having related words in Baltic and German languages.

In spite of this, it is believed by many scholars that the bulk of common Slavic agricultural terminology are either latest derivatives or assimilated from other languages. [22, p. 113].

We must also emphasize that in case a Slavic name has no IE analogues, it is regarded, at least, in half the cases, as a new derivative. If a Slavic name has a number of IE analogues, it is considered as a borrowing from an unknown language; finally, the only name, лук "onion”, is regarded as a German borrowing with indefinite further etymology.

"Of course, the accumulation of agricultural terminology in the Slavic language has been going on for a long time. In any case, it is quite obvious that the speakers of the common Slavic language at the middle stage of its development were well acquainted with agriculture and already had a significant supply of relevant vocabulary that has been preserved in Slavic languages to the present. This can be said not only about the names of cultivated plants, but also about the names of agricultural tools, various types of agricultural labor and agricultural products. General Slavic agricultural vocabulary as a whole is very different from the corresponding vocabulary of other Indo-European languages, representing a peculiar and unique complex” [22, p. 114].

Reading the material of the latter quotation, we can see a contradiction.

On the one hand, the so-called "historical-cultural restrictions" imply a relatively late appearance of Slavs in historical arena, and it is obvious, that the acquiring by people of a production technology new to them but known to the neighboring peoples would have to be accompanied by borrowing the names of tools and objects of processing. 
On the other hand, only Slavs had formed a "peculiar and unique complex" of agricultural vocabulary that differs from IE vocabulary, despite the influence of allegedly more advanced tribal IE groups.

To solve this contradiction, we offer a more careful etymological analysis of several agricultural names which are considered borrowed [23]. It should be here noted that crops with original Slavic names had been discovered in the Middle East and spread quickly to the Eastern Mediterranean. These are barley and wheat, the oldest crops, as well as millet, widely known from the 3rd millennium BC, including Europe and North Africa. Cultivated peas also spread throughout Europe from the eastern Mediterranean.

We will examine in more detail Slavic names for onion (used in food long before Christian era in Iran, China and Mediterranean countries), carrot (carrot seeds have been discovered by archeologists during excavations among all the Mediterranean coast (including North Africa) and mint (kinds of mint originate from the Middle Asia, and also from the Mediterranean).

In our etymological studies, we will be guided by the following rule: a word has the most probable source in that language group where it is common and has the most meaningful motivation.

Лyк “onion"

The onion name is common in Slavic: Rus. лук, OCS лоукъ, Bulgarian лу́к, Serbo-Croatian лÿ, Slovenian lùk, Czech luk, Polish tuk.

According to Vasmer, (see «лук» in [7]) it is borrowed from German *lauka-. If we search for the meaning of the last one in the article "Reconstruction:Proto-Germanic/laukaz" [8]: "the etymology is unknown. Finally, possibly, from Proto-IE *lewg- 'to bend'”. We can find in [10] two similar IE prototypes with the meaning "to bend" by S. A. Starostin: *lug- and *lenk $\left({ }^{w}\right)-$. From the second one, Slavic cognate words meaning "bow” and 'to bend' can be derived.

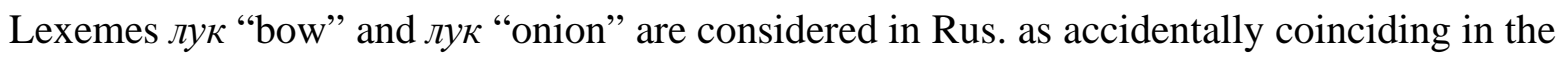
final pronunciation homonyms, in spite of corresponding meanings of IE prototypes. Should we consider this conclusion as the final? If we have in mind that the plant could be named this way because of the similarity of its growing pedicels to arrows (they are still called this way in Rus.: стрель "arrows"), the common Slavic lexeme *lokb / *lękb (compare OCS лжкъ and Polish łęk) which contains nasal vowel $q / e$ in its stem and means "bow" could be considered as the prototype of this plant name. In this case, this onion name was borrowed by Germans, and this can explain the absence of deeper etymology in German.

The Polish form $t u k$ "onion” devoid of nasal vowels probably appeared as a result of latest borrowing from German (that means the opposite direction of borrowing), or from some other Slavic language after the reduction of nasals. Compare also Lett. luõks "onion” (borrowed from

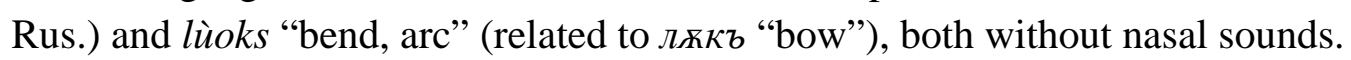

The IE name of onion *kermus- / *kremus- [10], [8] is not related to German, Slavic and Baltic names, the same is true for Latin and Persian names for onion.

Морковь "carrot"

Compare Slavic analogues of морковь “carrot” with Slavic analogues of меркнуть “darkle, fade”, мapamb “mackle, stain”:

- Bulgarian мо́рков - мръква "getting dark";

- Serbo-Croatian мрквва - мркикути "to fade"; 
- Slovenian mŕkəv - mŕkniti "to fade";

- Czech mrkev - OCzech mrknúti, Czech smrknouti "to get dark, to blink";

- Polish marchew - Polish marać "to make dirty";

- Upper Lusatian morchej, Lower Lusatian marchwej - Upper Lusatian marać, mórać "to smutch".

The semantical relation between морковь and маркий (less often - archaic марковатый, article "марать" in [20, р. 897-898]) is evident: initially carrot tubers were dark violet and stained everything touching them. According to absence of cognates in Scandinavian, it is more likely, that there was no common German lexeme meaning "carrot". In this case, OE more, OHG mor(a)ha "a root of a plant or a tree", OSax. moraha "carrot" (see "more" in [8]) are Slavic borrowings.

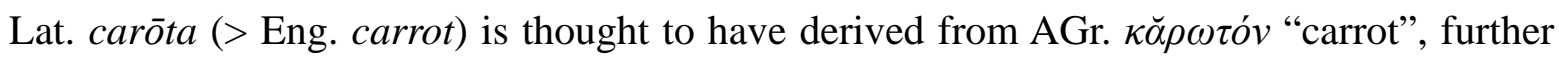
the connection with IE *ker- "horn" [8] is supposed, allegedly because of the similarity of carrot tubers with horns. These names are not related with the history of Slavic carrot names.

Mama "mint"

Mяma "mint" is a common Slavic suffixal derivative with the suffix -t-, as in nяma "heel" OCS пьАти "stretch; kick", сито "sieve" OCS стоmи "sow; sieve". Contrary to Vasmer, it was not derived from Lat. mentha (see "мята" in [7]), but is related to OCS мАти "to crumple" (a crumpled mint leaf has a strong smell) with a related lexeme minti "trample" in Lithuanian. By the by, the Latin lexeme with [en] should be regarded as originating from a prototype with a nasal vowel in its stem [24, p. 114-122], not vice versa.

Ancient mythology confirms the sense of "crumpled, trampled": there was allegedly a nymph named Miv $\theta \eta$ in the Underground Kingdom; Hades left her having fallen in love with Persephone (Lat. Proserpina); Miv $\theta \eta$ could not stop complaining and swearing her rival, for which she was trampled by her mother Demeter; then garden mint grew on this place. Harper considers that name of the nymph could be borrowed from a lost Mediterranean language (see "mint (n.1)" in [17]). We argue that her name could be either of Proto-Slavic or Proto-Baltic origin.

All of the considered here and in [3] plant names have clear semantics in the Common Slavic language: лук "a plant with arrows" (cognate with OCS лккъ "bow", Lett. lùoks "arch"), морковь "something that makes dirty" (cognate with марковатый "making dirty"), pena "dug out” (cognate with pynamu "dig”), горox "reaching up” (Eng. up = ORus. гopé, cognate with гора "mountain"), мята "crumpled, trampled" (cognate with м.ти "to crumple"), резеда "having sharp odor" (cognate with рғзати "cut”, *ргзъкъ "sharp").

Here are several words denoting agricultural inventory without a detailed review: the terms соха "a predecessor of plough", лопата "spade", вильь, гумно and many others are original Slavic.

It is difficult to consider as an accident the correspondence of the Mediterranean homeland of plants and the possibility of the Slavic etymology of the names of these plants, by virtue of a noticeable number of such coincidences. But in general, the uniqueness of the complex of Slavic agricultural terms mentioned by F. P. Filin in [22] can be explained by isolation of Proto-Slavs in the Eastern Mediterranean, including the Balkans.

Agricultural terms, unlike the names of exotic animals, fish, and many watercraft details discussed in previous works, could be preserved in the language even after migration to the north, 
since the seeds and agricultural inventory could and should be taken by migrants to provide themselves with food in a new place, which cannot be said of large vessels and southern fish.

Let us recall now that not only traces of previous habitats in the researched ethnic group vocabulary can say us about their linguistical ancestral home, but also traces of borrowings from this ethnic group vocabulary to the languages of ethnic groups that replaced the researched one on the territory that used to be its habitat. This way, for example, there are Baltic fish names (salmon and eel) [25, p. 198] discovered in Baltic-Finnish vocabulary, which have been borrowed from Baltic languages. These borrowings suggest that Finns pressed out Balts near to the Baltic Sea (not vice versa) with perception of unknown fish names from Balts.

Similarly, in the search for the area of formation of the Proto-Slavic language we will be helped also by terms with an unclear etymology in the languages of the peoples now living in this area that could be etymologized as borrowings from the language of Proto-Slavic predecessors.

Finding such terms would allow Proto-Slavs to be regarded as more ancient inhabitants of this mysterious zone, while the ethnic groups now living on it were newcomers from other areas who perceived part of the culture of ancient Slavs. These terms inevitably become forgotten by emigrants if the corresponding phenomena are not found in new habitats. But at later contacts with the new population of places previously abandoned by Proto-Slavs, some of these terms could return to their language (or descendant languages) through a sequence of borrowings, the terms being distorted by phonetics of the newcomers.

Surprisingly, among these terms there are:

- names of African endemics: жираф "giraffe” and зебра "zebra” and, probably, бегемот "hippopotamus"; also, cmpayc "ostrich"; although ostrich is not an African endemic, it is not found anywhere in Europe [26];

- names of some Mediterranean fish: тунец "tuna”, макрель "mackerel”, скорпена “scorpion fish", акула "shark” [27];

- Mediterranean and Balkan toponyms and hydronyms: Лесбос "Lesbos”, Kunp “Cyprus”, Ядран “Adriatic Sea”, Рено “Reno”, Триест “Trieste”, Болонья “Bologna” etc. [28].

All these names officially have unclear final etymologies, but upon careful consideration, they are lexemes with Slavic etymology which have phonetically distorted in acts of borrowing.

We can add that names of some African animals known beyond Africa have preserved in Russian without distortion:

- вельблждъ “camel”, literally - “walking much”;

- обозинда < ббозьнна "monkey”, literally - "ugly face”, from similar to the original” (seе «обозињна» and «обозъ» in [29, p. 32]) - compare Lat. semantic parallel / calque simia "monkey" similis "similar";

- слонъ "elephant”.

And only the memory of African endemics had been erased over time in the source language, so that their names had to be borrowed by Slavs from the receiver languages.

\section{Baltic-Thracian relations}

Since the ancestors of Balts were neighbors of the ancestors of Slavs in the area of BalkanCarpathian metallurgical province, one should expect not only the connections of the Pre-Slavic vocabulary with the vocabulary of the languages of southern Europe, but also the connections of Proto-Baltic vocabulary with the vocabulary of the southern neighbors of the Baltic ancestors. 
O. N. Trubachev noted the connection of the Baltic onomastics with ancient onomastics of the Balkans. For comparison, he offered:

- hydronyms Thracian Serme - Lith. Sermas;

- names Thracian Kerses - OPrus. Kerse;

- Thracian Edessa, name of a city, - Baltic Vedosa, Upper Dnieper hydronym;

- Thracian Zaldapa - Lith. Zeltupe and other;

- Thracian Prousa, name of a city in Bithynia - Baltic Prus-, ethnonym;

- Kaunos, a city in Caria, - Lith. Kaunas;

- Priene, a city in Caria, - Lith. Prienai.

Here we also should add the collections of comparisons by Ivan Duridanov [30], and also the Baltic etymology of the toponyms:

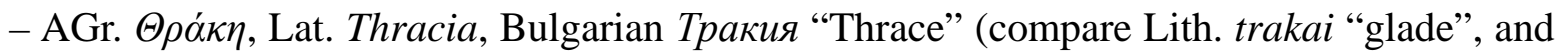
the city of Trakai);

- AGr. $\Sigma \pi \alpha \dot{\alpha} \rho \tau \eta$, Lat. Sparta “Sparta” (compare OPrus. spartis “power”, sparts "powerful”, Lett. spars “power”);

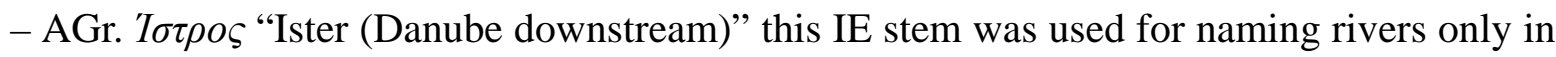
Baltic habitat;

- a Thracian tribe Odrisses (compare hydronim Odra).

Even if these correspondences do not prove close relations between the Thracian and the Baltic languages, they are the sign of the influence of Thracian tribes upon Baltic ones in the 3rd millennium BC [5, p. 22-24]. For this reason we do not need to look for further etymology of the above southern names: for our purposes it is enough to show that Baltic names originated from Balkan sources.

Besides, Baltic stems *kal-, *kau- are found also in Ancient Greek vocabulary. There are many Ancient Greek names of copper and bronze objects related to the lexeme $\chi \alpha \lambda \kappa o ́ \varsigma$, for example, $\chi \alpha \dot{\alpha} \lambda \kappa \varepsilon \imath \varsigma$ "made of copper of bronze”, also "related to blacksmith craft", $\chi \alpha \lambda \kappa \varepsilon \tilde{\imath} o v$ “copper vessel”, also "forge”, $\chi \alpha \lambda \kappa \varepsilon v$ $\varsigma$ "brazier”, also "iron master, blacksmith”, a name of the blacksmith craft $\chi \alpha \lambda \kappa \varepsilon i \alpha$ (see above about the connection of the meanings "copper" and "blacksmith" in German) and $\chi \alpha \dot{\alpha} \nu v \psi$ "steal” (V. V. Ivanov, writes about the connection between $\chi \alpha \lambda \kappa o ́ \varsigma$ and $\chi \alpha \dot{\alpha} \nu \psi$, but he consider both names derived from Hittite *haflki [18, p. 98] > hapalki.

This terminological "indifference" to the nature of the material being processed allows us to say, contrary to V. V. Ivanov, of a semantic emphasis on the possibility of processing by hammering, and not on the material.

Thus, the more relevant comparison is $\chi \alpha \lambda \kappa o ́ \varsigma$ / $\kappa \alpha v \chi o ́ \varsigma$ "copper” (and $\chi \alpha \dot{\lambda} v \psi \psi$ "steel”) with Lith. kalti / kauti "to hammer, to forge", it gives us the possibility to suppose the ancient neighborhood of the ancestors of Balts and Ancient Greeks. Here is also $\chi \alpha \dot{\alpha} \lambda l \xi$ "beaten (crushed) stone” of unknown origin which is evidently not related to copper or steel, however. All these lexemes differ only in extensions of the stem $\chi \alpha \lambda-(\kappa \alpha v-)<$ Baltic *kal-/*kau-. The priority of Baltic forms is evident, since the concept "to beat" is more ancient than names of metals and crushed stone [15].

It is interesting that Trubachev notes the absence of Slavs in Baltic-Thracian contacts. This absence is quite explainable if we accept the opinion about the Thracian origin of Balts: in this case, the phrase "Baltic-Thracian contacts" becomes a tautology, and the contacts themselves in the Balkans were internal affair of Balts. 


\section{Slavic-Illyrian relations}

Illyrians were the western neighbors of Slavs in the 2nd millennium BC. Assuming the kinship between Thracians and Proto-Balts, we have the right to expect some kind of relations between Proto-Slavs and Illyrians. Not risking to directly associate Illyrians with the ethnogenesis of Proto-Slavs, O. N. Trubachev still talks about Illyrian-Slavic relations by which he explains the following correspondences between proper names:

- Doksy, a local name in Czech Republic, compare Daksa, an island in the Adriatic Sea, and a gloss daksa thalassa. "Epeirotai (Hesihius)";

- Дукля, a mountain pass in the Carpathians, compare Дукльа in Montenegro, Doklea (Ptolemy);

- Licicaviki, a name attributed to a Slavic tribal name, but explainable only as Illyrian *Liccavici, compare Illyrian personal names Liccavus, Liccavius and a local name Lika in Yugoslavia [5, p. 26].

The origin of North-Eastern Italian toponyms Bologna and Reno is also of interest in the context of Illyrian-Slavic relations.

The city Bologna located in the north of Italy was originally called FELIYA [welzna] by Etruscans (see "Felsina" in [8]). Comparing the Etruscan name Welzna with Lett. vęlgs "wet, wetness", we obtain the possible Baltic semantic of the name of the city: "Wet”. The Baltic etymology of the Etruscan name is semantically plausible, since the city of Bologna, located between the valleys of the Reno and Savena rivers, was regularly flooded with spring floods. The name Bologna is naturally explainable with ORus. болонье "flood meadow, lowland".

The etymology of Reno < ORus. proнb "shoal" organically fits here. The Reno river has only recently become navigable and only in the lower reaches, for the most part of its shallow riverbed goes through swamps of the river Po valley, hence the meaning of the name: "Shallow".

Reuse of toponyms is also in favor of migration of Slavs from Illyrian territory to the North of Europe: Bologna (Bulåggna) > Boulogne (-sur-mer), Reno $>$ P $\tilde{\eta}$ vos (the ancient name of the Rhine), also Balaton Lake > Baltic Sea:

- Boulogne was subject to high tides, like Bologna was subject to spring floods;

- Rhine, just like Reno, was a flat shallow river;

- Baltic Sea, like Balaton, was semantically associated with swamps due to its muddy coastal water (compare Alb. baltë "mud, swamp, clay, earth”, of Illyrian origin (see "болото” in [7]), OCS блато [blato], also compare semantically Cimbric name of the sea, Morimarusa, according to Pliny the Elder, an obvious cognate of Welsh (Cymraeg) Môr Marw "Dead Sea”), or, probably, with white color (Lith. báltas "white”, related to OCS блато and Alb. baltë "swamp"), so there should be no semantic objections.

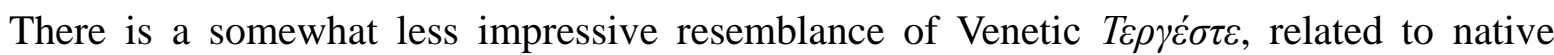
Slavic * Тържиште (compare Serbian тржиште), literally - “a market place” (Adriatic, North East of Italy, now Trieste) and Rus. Торжок (literally - also “a market place”, “Tver region”).

See more details, in particular, about assimilation [1] > [n] in Lat. Bononia, in [28].

Studies of relations of Baltic and Slavic languages with Thracian and Illyrian languages, respectively, do not contradict O. N. Trubachev's idea of language consolidation, in this case, including the Western Black Sea region. This consolidation led to the formation of the ProtoBalto-Slavic language union, the Proto-Slavic component of which later became closer to Iranian [1, p. 41] (V. V. Sedov refers here to A. I. Sobolevsky). 


\section{Finnish borrowings in Eastern Slavic and remaining Finnish toponyms}

Further on, just like Finns borrowed names of some Baltic fish from Balts, Eastern Slavs borrowed names of northern fish not familiar to them from Finno-Ugric languages. D. N. Shmelev gives a list of numerous borrowed names of fish according to written sources [31, p. 192-194], in particular: камбала "flounder" (compare Finnish kampala, Yakut kāmbala, Kildin Saami kãmbel), кopexa "smelt" (compare Karelian, Olonets kuoreh, Vepsian koŕeh, Finnish kuore), кумжа "brown trout” (compare Finnish kumsi, Karelian *kumži, Saami P. kuи̃dža, Kildin Saami kuйdtša), палтус, палтас, палтос "halibut” (compare Finnish pallas, gen. paltaan “flounder (river)”, Saami K. pāldes, gen. pāltazi “a kind of flounder”), ряпушка "vendace” (compare Vepsian räpus, Finnish rääpys, gen. rääpyksen, Estonian rääbis, rääbus), харьюс "grayling” (compare Vepsian hard'uz, harjus, Karelian harjuš, Finnish harju, harjus, gen. harjuksen "grayling"), and many others. Examples to compare with are from [7]. FinnoUgric borrowings of the names of northern fish into Slavic languages indicate that Slavs appeared in northern Europe later than the Finno-Ugric peoples.

It is well-known also that there are many Finnish by origin toponyms (names of villages, rivers and lakes) on the territory that once belonged to Novgorod principality. These facts are natural effect of later presence of Slavs in the North-East of Europe.

We should note that among the North European borrowings of such terms to Slavic languages there are no reliable borrowings from Germanic. On the contrary, in Swedish language (the only one from the Scandinavian) one of swamp names, träsk, was likely borrowed from ORus, compare Swedish träsk and ORus. трясъкъ "shaking, unsteady", Rus. трясина "morass". This might mean that Germans inhabited North Europe later than Slavs, which could explain an unexpectedly little number of traces of German lexis in Slavic languages, marked by Shchukin [32, p. 117].

Germanic names of horse, possibly, also indicate the latest arrival of Proto-Germanic tribes to Europe. Among European languages, belonging to the IE family, only in Germanic there are no names originating from PIE *kab- "horse" [10] (compare AGr. $\kappa \alpha \beta \alpha \dot{\alpha} \lambda \lambda \eta \varsigma$, Welsh ceffyl, Lat. caballus, Lith. kumele, Rus. кобыла).

Furthermore, only in Germanic language group there are Dutch paard and German Pferd "horse” which are usually derived from late Lat. paraveredus "spare horse” [17] from Greek para + veredus, from OHebr. pered "mule" [33]. We suppose that Dutch paard and German Pferd originated directly from related Semitic lexemes (Akkadian perdum "mule” [34, p. 202], OHebr. pärä "wild donkey” [35, p. 317], OHebr. pered “mule”), and that only English palfrey and OHG pfarifrid had been derived through Lat. palafredus / paraveredus.

Conclusion. The research of the linguistic ethnogenesis of Slavs has shown that the ProtoSlavic language was forming at a territory where they:

- mined from ores copper, iron, tin, lead and silver, wherein mining, blacksmithing and metallurgical terminology of Slavs is native;

- formed original agricultural vocabulary, crops of the Eastern Mediterranean and SouthWestern Asia having native names for them;

- had extended trade relationships, throughout sea, in that number;

- at last, but not the least, named at least two African endemics and some species of Mediterranean fauna and flora: these names had been borrowed into languages of newly coming 
expansive ethnic groups and thus spread all over Europe; later many of these names were lost for Slavs, who had left Mediterranean, and finally were borrowed back into Slavic languages...

Relations of the Proto-Slavic and Proto-Baltic languages between each other and also with Paleo-Balkan languages, Ancient Greek language and languages of the Iranian group suggests that both languages, more likely, originated in the Eastern Mediterranean.

Absence of traces of a prolonged cohabitation or neighboring habitation with Germans in the language of Slavs is justified by relatively late arrival of Germans to Central and North Europe. This removes the known objection to the Vistula-Oder "intermediate ancestral home" of Slavs. The intermediateness of this and the East European ancestral home follows from the absence of the original names of some northern fish, animals and plants in Slavic languages.

This way, according to the totality of the reviewed factors, we have the right to consider as quite well-founded the Mediterranean localization of the Proto-Slavic ancestral home. It was in this area that in the process of Pre-Slavic tribes' large-scale cooperation in the 4th Millennium BC (the time of activity of Balkan-Carpathian metallurgical province) the Proto-Slavic language could have started its forming through tribal dialects interaction.

\section{REFERENCES}

1. Sedov, V.V. (1994), Ocherki po arkheologii slavyan [Essays on the archeology of the Slavs], IA RAN, Moscow, RUS.

2. Trubachev, O.N. (1982), "Linguistics and ethnogenesis of the Slavs. Ancient Slavs according to etymology and onomastics", Voprosy Jazykoznanija, no. 4, pp. 10-26.

3. Telezhko, G.M. (2020), "Ethnogenesis of the Slavs in the Eastern Mediterranean (according to linguistic data)", Universum: filologiya i iskusstvovedenie, no. 3 (71), available at: https://7universum.com/ ru/philology/archive/item/9087 (accessed 28.07.2020).

4. Sedov, V.V. (2002), Slavyane. Istoriko-arkheologicheskoe issledovanie [Slavs. Historical and archaeological research], Yazyki slavyanskoi kul'tury, Moscow, RUS.

5. Trubachev, O.N. (2003), Etnogenez i kul'tura drevneishikh slavyan. Lingvisticheskie issledovaniya [Ethnogenesis and culture of the ancient Slavs. Linguistic research], Nauka, Moscow, RUS.

6. Otkupshchikov, Yu.V. (1989), "Balto-Slavic handicraft vocabulary (names of metals, metallurgy, blacksmithing)", Slavyane: etnogenez i etnicheskaya istoriya [Slavs: ethnogenesis and ethnic history], in Gerd, A.S. and Lebedev, G.S. (ed.), Izd-vo LGU, Leningrad, USSR, pp. 44-52.

7. Vasmer, M. (1986), Russisches etymologisches Worterbuch, Transl. by Trubachev, O.N., in Larin, B.A. (ed.), in 4 vol., 2nd ed., Progress, Moscow, USSR, available at: http://etymolog.ruslang.ru/index.php?act=contents\&book=vasmer (accessed 07.07.2020).

8. Wiktionary, available at: https://en.wiktionary.org (accessed 07.07.2020).

9. Trubachev, O.N. (2008), Trudy po etimologii: Slovo. Istoriya. Kul'tura [Works on etymology: Word. History. Culture], vol. 3, Rukopisnye pamyatniki Drevnei Rusi, Moscow, RUS.

10. "Indo-European etymology", The Global Lexicostatistical Database, available at: http://starling.rinet.ru/cgi-bin/query.cgi?basename=ldatalielpiet\&root=config\&morpho=0 (accessed 07.07.2020).

11. Shaposhnikov, A.K. (2010), "Nestinarski igri - an experience of semiotic description", Linguistique Balkanique, vol. XLIX, no. 1-2, pp. 143-149.

12. Vinogradov, V.V. (1978), "The main problems of studying the education and development of the Old Russian language", Izbrannye trudy. Istoriya russkogo literaturnogo yazyka [Selected works. History of the Russian literary language], Nauka, Moscow, USSR, pp. 65-151. 
13. Trubachev, O.N. (1999), "Silver", Indoarica v Severnom Prichernomor'e [Indoarica in the Northern Black Sea Region], Nauka, Moscow, RUS, pp. 76-82.

14. Chernykh, E.N. (2013), Kul'tury nomadov v megastrukture Evraziiskogo mira: $v 2$ t. [Culture of nomads in the megastructure of the Eurasian world: in 2 volumes], vol. 1, Yazyki slavyanskoi kul'tury, Moscow, RUS.

15. Telezhko, G.M. (2018), "The analysis of the names of copper in languages of different ethnoses", Universum: filologiya i iskusstvovedenie, no. $2(48)$, available at: URL: http://7universum.com/ru/philology/archive/item/5508 (accessed 07.07.2020).

16. Chernykh, E.N. (2006), "Philosophy of metal", $V$ mire nauki [In the world of science], no. 7, pp. 62-65.

17. Harper, D., Online Etymology Dictionary, available at: https://www.etymonline.com/ (accessed 07.07.2020).

18. Ivanov, V.V. (1983), Istoriya slavyanskikh i balkanskikh nazvanii metallov [History of Slavic and Balkan names of metals], Nauka, Moscow, USSR.

19. Hennig, R. (1961), Nevedomye zemli [Terrae Incognitae], Transl. by Vol'fson, L.F. and Persits, R.Z., vol. 1, Izdatel'stvo inostrannoi literatury, Moscow, USSR.

20. Dal', V.I. (1865), "Tin", Tolkovyi slovar' zhivago velikoruskago yazyka. Chast' 2. I-O [Explanatory Dictionary of the Living Great Russian Language. Part 2. I-O], Tipografiya A. Semena, Moscow, p. 1249.

21. Kogan, L.E. and Lezov, C.V. (2009), "Akkadian language", Yazyki mira: Semitskie yazyki. Akkadskii yazyk. Severozapadnosemitskie yazyki [Languages of the World: Semitic Languages. Akkadian language. Northwest Semitic languages], in Belova, A.G., Kogan, L.E., Lezov, S.V. and Romanova, O.I. (ed.), Academia, Moscow, RUS, pp. 113-177.

22. Filin, F.P (1962), Obrazovanie yazyka vostochnykh slavyan [Creation of the language of the Eastern Slavs], Izd. AN SSSR, Moscow, Leningrad, USSR.

23. Telezhko, G.M. (2018), "Criticism of the some supposed sources for Slavic agricultural vocabulary", Universum: filologiya i iskusstvovedenie, no.1(47), available at: http://7universum.com/ru/philology/archive/item/5445 (accessed 29.01.2020).

24. Telezhko, G.M. (2019), "On the Divergence of a Proto-Indo-European Velar Syllabic Nasal in Indo-European Languages", DISCOURCE, vol. 5, no. 5, pp. 114-122. DOI: 10.32603/2412-8562-2019-55-114-122.

25. Napol'skikh, V.V. (2002), "Prehistory of the peoples of the Uralic language family", Istoriya tatar s drevneishikh vremen $v$ semi tomakh. T. 1. Narody stepnoi Evrazii v drevnosti [History of the Tatars from ancient times in seven volumes. Vol. 1. Peoples of the steppe Eurasia in antiquity], in Usmanov, M. and Khakimov, R. (ed.), Rukhiyat, Kazan', RUS, pp. 195-203.

26. Telezhko, G.M. (2017), "Of etymology of names of some species of African fauna”, Universum: filologiya $i$ iskusstvovedenie, no.9(43), available at: http://7universum.com/ru/philology/ archive/item/5132 (accessed 29.01.2020).

27. Telezhko, G. M. (2018), "Criticism of the "sea fish" argument in the problem of the Slavic localization", Universum: filologiya i iskusstvovedenie, no.1(47), available at: http://7universum.com/ru/philology/archive/item/5422 (accessed 29.01.2020).

28. Telezhko, G.M. (2018), "Analysis of names of gold in languages of different ethnoses", Universum: filologiya $i$ iskusstvovedenie, no. 4 (50), available at: http://7universum.com/ru/philology/ archive/item/5757 (accessed 29.01.2020).

29. Sreznevskii, I.I. (1902), Materialy dlya slovarya drevne-russkago yazyka po pis'mennym pamyatnikam. Tom 2. L-P [Materials for the dictionary of the Old Russian language on written monuments. Vol. 2. L-P], Tipografiya Imperatorskoi Akademii nauk, SPb, RUS. 
30. Duridanov, I. (1976), Ezik"t na trakite [The language of the Thracians], Nauka i izkustvo, Sofia, Bulgaria.

31. Shmelev, D.N. (1961), "Borrowings from the Baltic Finnish languages in the old Russian written monuments", Voprosy slavyanskogo yazykoznaniya [Questions of Slavic linguistics], iss. 5, Izdvo Akademii nauk SSSR, Moscow, USSR, pp. 191-199.

32. Shchukin, M.B. (1997), "The birth of the Slavs", Stratum: struktury i katastrofy [Stratum: structures and catastrophes], Nestor, SPb., RUS, pp. 110-147.

33. “G”, Vocabvlarivm Latinorvssicvm Magnvm, available at: http://linguaeterna.com/ vocabula/list.php?letter=G (accessed 27.01.2020).

34. Kogan, L.E. (2009), "Old Assyrian dialect", Yazyki mira: Semitskie yazyki. Akkadskii yazyk. Severozapadnosemitskie yazyki [Languages of the World: Semitic Languages. Akkadian language. Northwest Semitic languages], in Belova, A.G., Kogan, L.E., Lezov, S.V. and Romanova, O.I. (ed.), Academia, Moscow, RUS, pp. 195-204.

35. Kogan, L.E. and Lezov, C.V. (2009), "Hebrew”, Yazyki mira: Semitskie yazyki. Akkadskii yazyk. Severozapadnosemitskie yazyki [Languages of the World: Semitic Languages. Akkadian language. Northwest Semitic languages], in Belova, A.G., Kogan, L.E., Lezov, S.V. and Romanova, O.I. (ed.), Academia, Moscow, RUS, pp. 296-374.

\section{Information about the author.}

Georgiy M. Telezhko - Can. Sci. (Engineering) (1997), Director of IP “Georgiy Mikhailovich Telezhko”, 167-8 Fontanka riv. emb., St Petersburg 190121, Russia. The author of 49 scientific publications. Areas of expertise: comparative linguistics, atmospheric physics, relativity theory. E-mail: yurate@bk.ru

\section{СПИСОК ЛИТЕРАТУРЫ}

1. Седов В. В. Очерки по археологии славян. М.: ИА РАН, 1994.

2. Трубачев О. Н. Языкознание и этногенез славян. Древние славяне по данным этимологии и ономастики // Вопросы языкознания. 1982. № 4. С. 10-26.

3. Тележко Г. М. Этногенез славян в Восточном Средиземноморье (по лингвистическим данным) // Universum: филология и искусствоведение. 2020. № 3 (71). URL: https://7universum.com/ru/philology/archive/item/9087 (дата обращения: 28.07.2020).

4. Седов В. В. Славяне. Историко-археологическое исследование. М.: Языки славянской культуры, 2002.

5. Трубачев О. Н. Этногенез и культура древнейших славян. Лингвистические исследования. М.: Наука, 2003.

6. Откупщиков Ю. В. Балто-славянская ремесленная лексика (названия металлов, металлургия, кузнечное дело) // Славяне: этногенез и этническая история: межвуз. сб. / под ред. А. С. Герда, Г. С. Лебедева. Л.: Изд-во Ленингр. ун-та, 1989. С. 44-52.

7. Фасмер М. Этимологический словарь русского языка: в 4 т. / пер. с нем. О. Н. Трубачева; под ред. Б. А. Ларина. 2-е изд. М.: Прогресс, 1986. URL: http://etymolog.ruslang.ru/index.php?act= contents\&book=vasmer (дата обращения: 07.07.2020).

8. Wiktionary. URL: https://en.wiktionary.org (дата обращения: 07.07.2020).

9. Трубачев О. Н. Труды по этимологии: Слово. История. Культура. Т. 3. М.: Рукописные памятники Древней Руси, 2008.

10. Indo-European etymology // The Global Lexicostatistical Database. URL: http://starling.rinet.ru/cgi-bin/query.cgi?basename=ldatalielpiet\&root=config\&morpho=0 (дата обращения: 07.07.2020). 
11. Шапошников А. К. Нестинарски игри - опыт семиотического описания // Linguistique Balkanique. 2010. T. XLIX, № 1-2. C. 143-149.

12. Виноградов В. В. Основные проблемы изучения образования и развития древнерусского языка // Избранные труды. История русского литературного языка. М.: Наука, 1978. С. 65-151.

13. Трубачев О. Н. Серебро // Indoarica в Северном Причерноморье. М.: Наука, 1999. С. 76-82.

14. Черных Е. Н. Культуры номадов в мегаструктуре Евразийского мира: в 2 т. Т. 1. М.: Языки славянской культуры, 2013.

15. Тележко Г. М. Анализ названий меди в языках разных этносов // Universum: Филология и искусствоведение. 2018. № 2 (48). URL: http://7universum.com/ru/philology/archive/item/5508 (дата обращения: 07.07.2020).

16. Черных Е. Н. Философия металла // В мире науки. 2006. № 7. С. 62-65.

17. Harper D. Online Etymology Dictionary. URL: https://www.etymonline.com/ (дата обращения: 07.07.2020).

18. Иванов В. В. История славянских и балканских названий металлов. М.: Наука, 1983.

19. Хенниг Р. Неведомые земли / пер. с нем. Л. Ф. Вольфсон, Р. З. Персиц. Т. 1. М.: Издательство иностранной литературы, 1961.

20. Даль В. И. Оловина // Толковый словарь живаго великорускаго языка. Ч. 2. И-О. М.: Типография А. Семена, 1865. С. 1249.

21. Коган Л.Е., Лезов С. В. Аккадский язык // Языки мира: Семитские языки. Аккадский язык. Северозападносемитские языки / под ред. А.Г. Беловой, Л. Е. Когана, С. В. Лезова, О. И. Романовой. М.: Academia, 2009. С. 113-177.

22. Филин Ф. П. Образование языка восточных славян. М., Л.: Изд. АН СССР, 1962.

23. Тележко Г. М. Критический анализ некоторых предполагаемых источников славянской сельскохозяйственной лексики // Universum: Филология и искусствоведение. 2018. № 1 (47). URL: http://7universum.com/ru/philology/archive/item/5445 (дата обращения: 29.01.2020).

24. Telezhko G. M. On the Divergence of a Proto-Indo-European Velar Syllabic Nasal in IndoEuropean Languages // DISCOURCE. 2019. Vol. 5, № 5. P. 114-122. DOI: 10.32603/2412-8562-2019-5 5-114-122.

25. Напольских В. В. Предыстория народов уральской языковой семьи // История татар с древнейших времен в 7 томах. Т. 1. Народы степной Евразии в древности / под ред. М. Усманова, Р. Хакимова. Казань: Рухият, 2002. С. 195-203.

26. Тележко Г.М.К этимологии названий некоторых представителей африканской фауны // Universum: Филология и искусствоведение. 2017. № 9 (43). URL: http://7universum.com/ ru/philology/archive/item/5132 (дата обращения: 29.01.2020).

27. Тележко Г. М. Критика аргумента «морских рыб» в проблеме локализации прародины славян // Universum: Филология и искусствоведение. 2018. № 1 (47). URL: http://7universum.com/ ru/philology/archive/item/5422 (дата обращения: 29.01.2020).

28. Тележко Г. М. Анализ названий золота в языках разных этносов // Universum: Филология и искусствоведение. 2018. № 4 (50). URL: http://7universum.com/ru/philology/archive/item/5757 (дата обращения: 29.01.2020).

29. Срезневский И. И. Матеріалы для словаря древне-русскаго языка по письменнымъ памятникамъ. Т. 2. Л-П. СПб.: Типография Императорской Академии наук, 1902.

30. Дуриданов И. Езикът на траките. София: Наука и изкуство, 1976.

31. Шмелев Д. Н. Заимствования из прибалтийскофинских языков в старорусских памятниках письменности // Вопросы славянского языкознания. Вып. 5. М.: Изд-во Академии наук CCCP, 1961. С. 191-199.

32. Щукин М. Б. Рождение славян // Стратум: структуры и катастрофы. СПб.: Нестор, 1997. C. $110-147$. 
33. G // Большой латинско-русский словарь. URL: http://linguaeterna.com/vocabula/ list.php?letter=G (дата обращения: 27.01.2020).

34. Коган Л. Е. Староассирийский диалект // Языки мира: Семитские языки. Аккадский язык. Северозападносемитские языки / под ред. А. Г. Беловой, Л. Е. Когана, С. В. Лезова, О. И. Романовой. М.: Academia, 2009. С. 195-204.

35. Коган Л. Е., Лезов С. В. Древнееврейский язык // Языки мира: Семитские языки. Аккадский язык. Северозападносемитские языки / под ред. А. Г. Беловой, Л. Е. Когана, С. В. Лезова, О. И. Романовой. М.: Academia, 2009. С. 296-374.

\section{Информация об авторе.}

Тележко Георгий Михайлович - кандидат технических наук (1997), ИП «Георгий Михайлович Тележко», наб. р. Фонтанки, д. 167, кв. 8, Санкт-Петербург, 190121, Россия. Автор 49 научных публикаций. Сфера научных интересов: сравнительное языкознание, физика атмосферы, теория относительности. E-mail: yurate@bk.ru 